\title{
AN EVALUATION OF THE IMPLEMENTATION AND ADHERENCE TO THE CLINICAL PATHWAY OF DENGUE FEVER AT MUHAMMADIYAH GAMPING HOSPITAL, YOGYAKARTA
}

\author{
Budi Kusumah, Sri Sundari, Ekorini Listyowati \\ Masters Program in Hospital Management, Universitas Muhammadiyah Yogyakarta
}

\begin{abstract}
Background: A clinical pathway, also known as care pathway, integrated care pathway, critical pathway, or care map, is one of the main tools used to manage the quality in healthcare concerning the standardization of care processes. It is a patient's medical treatment path based on standard patient handling procedures adjusted to the medical infrastructure in a hospital. Clinical pathways are made based on cases that occur in a hospital and have the potential to spend large resources. One of the most common cases and getting attention is the dengue fever case. This study aimed to evaluate the implementation and adherence to the clinical pathway of dengue fever at Muhammadiyah Gamping Hospital, Yogyakarta.

Subjects and Method: This was a mixed method study conducted at Muhammadiyah Gamping Hospital, Yogyakarta. In the qualitative study, pediatricians and medical committee members were selected as informants. The data were collected by in-depth interview and document review.

Results: Clinical pathway of dengue fever was adequately implemented at about 89.5\%. Compliance with clinical pathway of dengue fever was $96.5 \%$. Obstacles in the implementation of clinical pathway included: (1) doctors unavailable for patient visit during holiday; (2) hospital management did not adequately support the implementation of clinical pathway.

Conclusion: Clinical pathway of dengue fever has been adequately implemented with a little support from the hospital management.

Keywords: clinical pathway, implementation, dengue fever

\section{Correspondence:}

Budi Kusumah. Masters Program in Hospital Management, Universitas Muhammadiyah Yogyakarta. Jl. Lingkar Selatan, Tamantirto, Kasihan, Bantul, Yogyakarta. Email: budikusumah.md@gmail.com. Mobile: 0281220097750
\end{abstract}

